\title{
Teaching Video NeuroImages: Needle-like central spikes evoked by hand tapping in Rett syndrome
}

Pratima Gulati, MD, Puneet Jain, MD, DM, Felippe Borlot, MD, Robert Munn, MD, and Ayako Ochi, MD, PhD Neurology ${ }^{\circledR}$ 2019;93:e422-e423. doi:10.1212/WNL.0000000000007843

\section{Correspondence}

Dr. Ochi

ayako.ochi@sickkids.ca

Figure EEG of the reported case
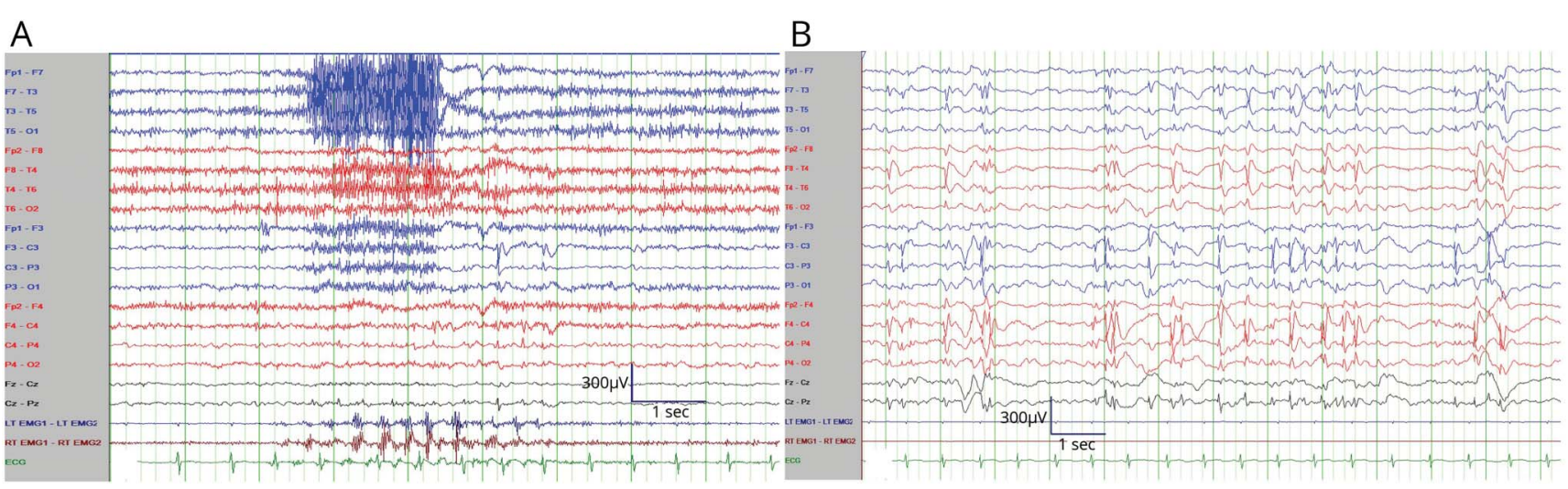

C

D
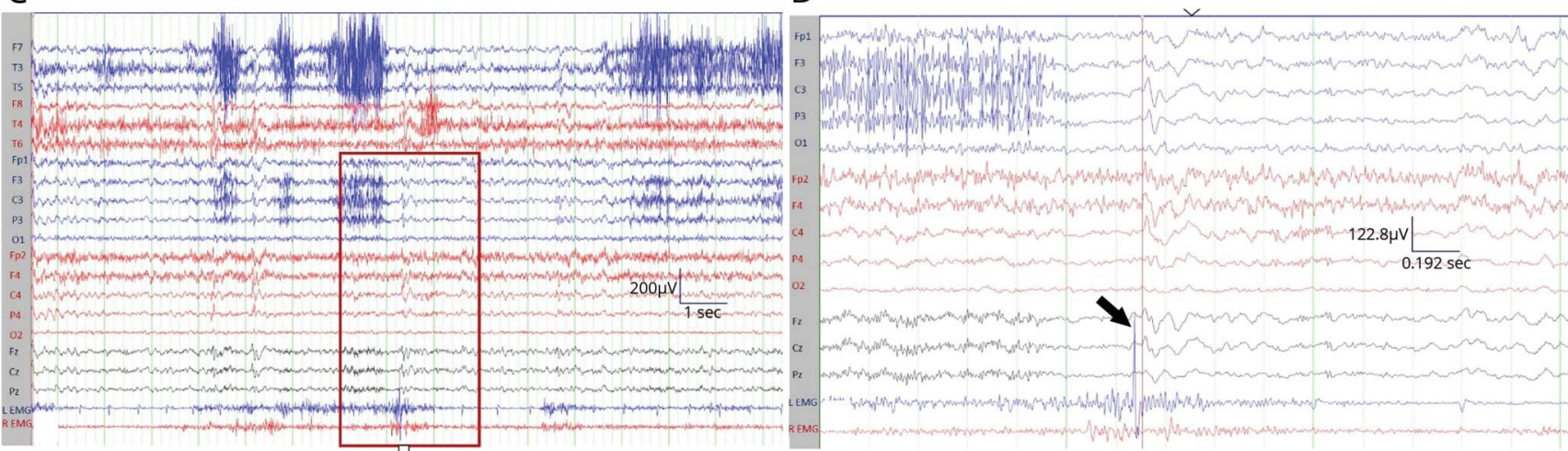

(A) There were runs of needle-like right and left central spikes independently or synchronously (initially lower amplitude and then higher amplitude) with bilateral hand tapping (note the bilateral deltoid EMG channels). (B) There was marked activation of these spikes during non-REM sleep without clinical signs. One such spike (in red box) is shown in referential montage (C) and on increased time base in (D), to demonstrate the relation between EMG and EEG spikes. The cursor (D) shows the onset of bilateral central spikes at C3 and C4. The latency between the left EMG spike (arrow) produced by hand tapping and the onset of C3 and C4 spikes was around $30 \mathrm{~ms}$, which may be consistent with somatosensory cortical evoked response. (Referential montage [system reference Oz], sensitivity $10 \mu \mathrm{V} / \mathrm{mm}$, low-frequency filter $1 \mathrm{~Hz}$, high-frequency filter $70 \mathrm{~Hz}$, sampling rate $256 \mathrm{~Hz}$ ).

A 4-year-old-girl with Rett syndrome (RS) presented with drug-resistant epilepsy since 4 years of age. Her video-EEG captured rhythmic hand tapping with bilateral central spike-and-waves (figure and video 1). Characteristic EEG features in RS include prominent central rhythmic theta activity during wakefulness and needle-like central spikes evoked by contralateral passive finger-tapping. These central spikes may represent exaggerated somatosensory evoked potential secondary to the presence of hyperexcitable motor and sensory cortices. Reflex seizures (focal and atonic) provoked by rhythmic hand pressure have been described in 2 children with
MORE ONLINE

- Video

$\rightarrow$ Teaching slides

links.lww.com/WNL/A930

From the Epilepsy Program (P.G., P.J., F.B., A.O.), Division of Neurology, Department of Paediatrics, The Hospital for Sick Children, Toronto, Canada; Division of Pediatric Neurology (P.J.), Department of Pediatrics, BL Kapur (BLK) Super Speciality Hospital, New Delhi, India; and Community Paediatric Neurologist (R.M.), North York, Toronto, Canada.

Go to Neurology.org/N for full disclosures. Funding information and disclosures deemed relevant by the authors, if any, are provided at the end of the article. 
RS. ${ }^{1}$ In contrast, hand clapping has also been reported to suppress continuous centrotemporal spikes. ${ }^{2}$ Thus, the clinical significance of these provoked central spikes is unclear.

\section{Study funding}

No targeted funding reported.

\section{Disclosure}

The authors report no disclosures relevant to the manuscript. Go to Neurology.org/N for full disclosures.

\section{Appendix Authors}

\begin{tabular}{llll}
\hline Author & Location & Role & Contribution \\
\hline $\begin{array}{l}\text { Pratima } \\
\text { Gulati }\end{array}$ & $\begin{array}{l}\text { The Hospital for Sick } \\
\text { Children, Toronto, } \\
\text { Canada }\end{array}$ & Author & $\begin{array}{l}\text { Provided clinical care to the } \\
\text { patient, analyzed the data, } \\
\text { drafted the manuscript for } \\
\text { intellectual content }\end{array}$ \\
$\begin{array}{l}\text { Puneet } \\
\text { Jain }\end{array}$ & $\begin{array}{l}\text { The Hospital for Sick } \\
\text { Children, Toronto, } \\
\text { Canada }\end{array}$ & Author & $\begin{array}{l}\text { Provided clinical care to the } \\
\text { patient, analyzed the data, } \\
\text { drafted the manuscript for } \\
\text { intellectual content }\end{array}$ \\
\hline
\end{tabular}

Appendix (continued)

\begin{tabular}{|c|c|c|c|}
\hline Author & Location & Role & Contribution \\
\hline $\begin{array}{l}\text { Felippe } \\
\text { Borlot }\end{array}$ & $\begin{array}{l}\text { The Hospital for Sick } \\
\text { Children, Toronto, } \\
\text { Canada }\end{array}$ & Author & $\begin{array}{l}\text { Provided clinical care to } \\
\text { the patient, analyzed the } \\
\text { data }\end{array}$ \\
\hline $\begin{array}{l}\text { Robert } \\
\text { Munn }\end{array}$ & $\begin{array}{l}\text { Community } \\
\text { Paediatric } \\
\text { Neurologist, North } \\
\text { York, Toronto, } \\
\text { Canada }\end{array}$ & Author & $\begin{array}{l}\text { Provided clinical care to } \\
\text { the patient, revised the } \\
\text { manuscript for } \\
\text { intellectual content }\end{array}$ \\
\hline $\begin{array}{l}\text { Ayako } \\
\text { Ochi }\end{array}$ & $\begin{array}{l}\text { The Hospital for Sick } \\
\text { Children, Toronto, } \\
\text { Canada }\end{array}$ & Author & $\begin{array}{l}\text { Provided clinical care to } \\
\text { the patient, analyzed } \\
\text { the data, interpreted the } \\
\text { data, revised the } \\
\text { manuscript for } \\
\text { intellectual content }\end{array}$ \\
\hline
\end{tabular}

\section{References}

1. Roche Martínez A, Alonso Colmenero MI, Gomes Pereira A, Sanmartí Vilaplana FX, Armstrong Morón J, Pineda Marfa M. Reflex seizures in Rett syndrome. Epileptic Disord 2011;13:389-393

2. Lv Y, Liu C, Shi M, Cui L. Clapping-suppressed focal spikes in EEG may be unique for the patients with Rett syndrome: a case report. BMC Neurol 2016; $16: 91$. 


\section{Neurology}

\section{Teaching Video NeuroImages: Needle-like central spikes evoked by hand tapping in Rett syndrome \\ Pratima Gulati, Puneet Jain, Felippe Borlot, et al.}

Neurology 2019;93;e422-e423

DOI 10.1212/WNL.0000000000007843

This information is current as of July 22, 2019

\section{Updated Information \& Services}

References

Subspecialty Collections

Permissions \& Licensing

Reprints including high resolution figures, can be found at: http://n.neurology.org/content/93/4/e422.full

This article cites 2 articles, 0 of which you can access for free at: http://n.neurology.org/content/93/4/e422.full\#ref-list-1

This article, along with others on similar topics, appears in the following collection(s):

All Pediatric

http://n.neurology.org/cgi/collection/all_pediatric

Autism

http://n.neurology.org/cgi/collection/autism

EEG

http://n.neurology.org/cgi/collection/eeg

Video/ EEG use in epilepsy

http://n.neurology.org/cgi/collection/video_eeg_use_in_epilepsy

Information about reproducing this article in parts (figures,tables) or in its entirety can be found online at:

http://www.neurology.org/about/about_the_journal\#permissions

Information about ordering reprints can be found online:

http://n.neurology.org/subscribers/advertise

Neurology ${ }^{\circledR}$ is the official journal of the American Academy of Neurology. Published continuously since 1951, it is now a weekly with 48 issues per year. Copyright @ 2019 American Academy of Neurology. All rights reserved. Print ISSN: 0028-3878. Online ISSN: 1526-632X.

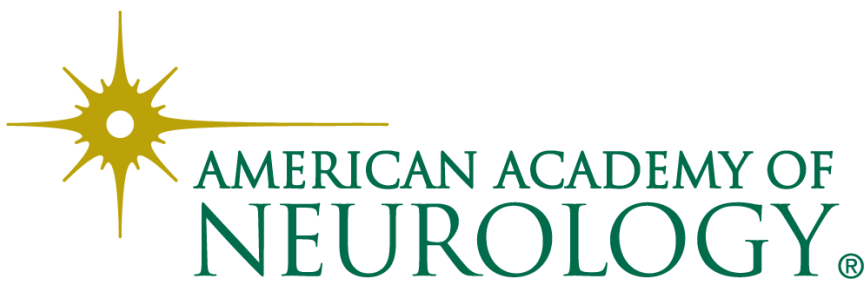

